\title{
FAKTOR-FAKTOR YANG BERHUBUNGAN DENGAN KUALITAS AIR MINUM SECARA BAKTERIOLOGIS PADA DEPOT AIR MINUM
}

\author{
Iis Rosyiah*Lilis Banowati**
}

\begin{abstract}
ABSTRAK
Air merupakan kebutuhan vital bagi manusia, pengadaan air minum harus memenuhi persyaratan yang sudah ditetapkan oleh pemerintah. Air minum aman bagi kesehatan apabila memenuhi persyaratan secara fisika, bakteriologis, kimia, dan radioaktif. Air merupakan media penyebar berbagai macam penyakit. Depot air minum merupakan salah satu pengolah air minum dimaksudkan untuk memperbaiki kualitas air sehingga aman dan tidak membahayakan bagi kesehatan masyarakat yang menggunakannya, saat ini yang murah dan mudah diperoleh. Tujuan penelitian ini adalah untuk mengetahui hubungan antara lokasi kegiatan depot air minum, bangunan depot air minum, sumber air baku depot air minum, alat produksi depot air minum terhadap kualitas air minum secara bakteriologis di Kabupaten Majalengka tahun 2017. Jenis penelitian ini adalah survey dengan pendekatan cross sectional. Subyek penelitian ini adalah seluruh Depot air minum di willayah Kabupaten Majalengka. Jumlah sampel sebanyak 60 depot air minum yang diambil secara proportional random sampling. Data diperoleh dengan wawancara dan observasi menggunakan ceklis pemeriksaan depot air minum dan dianalisis secara statistik menggunakan Uji Chi square pada tingkat kemaknaan 5\% (0,05). Hasil penelitian menunjukkan bahwa lokasi kegiatan depot air minum 56,7\% memenuhi syarat, bangunan depot air minum $90 \%$ memenuhi syarat, sumber air baku pada umumnya menggunakan PDAM dan alat produksi depot air minum memenuhi syarat 33\%. Hasil uji statistik didapatkan bahwa lokasi kegiatan $(\mathrm{p}=0,019)$ dan alat produksi $(\mathrm{p}=$ $0,000)$ mempunyai hubungan yang bermakna dengan kualitas air secara bakteriologis pada depot air minum di Kabupaten Majalengka tahun 2017.
\end{abstract}

Kata Kunci : Lokasi kegiatan, Bangunan, Sumber Air Baku, Alat Produksi, dan Kualitas Air Minum Secara Bakteriologis

\begin{abstract}
Water is vital for human needs, provision of drinking water must meet the requirements that are already set by the Government. Safe drinking water for health if it meets the requirements in physics, chemistry, and be bacteriologically radioactive. Water is the medium range of spreaders of the disease. Depot is one of the drinking water processing is intended to improve the quality of the water so it is safe and does not harm to the health of the community that use it, the moment is cheap and easy to obtain. The purpose of this research is to know the relation between the location of the activity depot, depot building drinking water, raw water sources drinking water depot, depot drinking water production tools to the quality of drinking water in be bacteriologically in Kabupaten Majalengka in 2017. Type of this research is a survey with cross sectional approach. The subject of this research is the entire drinking water Depot in Kabupaten Majalengka Area. The number of samples as many as 60 depot drinking water taken in proportional random sampling. The data obtained by interviewing and observations using the depot drinking water inspection checklist and statistically analyzed using Chi square Test on the level of significance of 5\% (0.05). The results showed that the location of the depot drinking water activities $56.7 \%$ qualified, building depot drinking water $90 \%$ qualified, raw water sources in General using TAPS and tool production of qualified drinking water depot 33\%. The results of statistical tests is obtained that the location of activity $(\mathrm{p}=0.019)$ and production $(\mathrm{p}=0.000)$ have a meaningful relationship with water quality in drinking water be bacteriologically at depot in Kabupaten Majalengka in 2017. Keywords : location, activities, buildings, Raw water source, means of production, and the quality of drinking water In be bacteriologically
\end{abstract}

\footnotetext{
*Alumni PSKM STIKes Cirebon Lulus Tahun 2017

** Staf Pengajar Program Studi S1 Kesehatan Masyarakat STIKes Cirebon
} 


\section{PENDAHULUAN}

Air merupakan suatu sarana utama untuk meningkatkan derajat kesehatan masyarakat. Air merupakan salah satu media dari berbagai macam penularan penyakit, terutama penyakit diare. Penyakit diare dapat ditularkan melalui penyediaan air.Untuk menghindari masuknya bibit penyakit melalui air ke dalam tubuh, maka pengolahan air baik berasal dari sumber, jaringan transmisi atau distribusi mutlak diperlukan. Hal ini untuk mencegah terjadinya kontak antara bakteri sebagai sumber penyakit dengan air. ${ }^{1}$

Dalam peraturan perundang-undangan nomor 16 tahun 2005 tentang Sistem Pengelolaan Air Minum (SPAM), dijelaskan bahwa istilah air bersih tidak digunakan lagi dan digantikan dengan istilah air minum. Beberapa jenis air minum, antara lain : air kemasan, air yang didistribusikan melalui pipa untuk keperluan rumah tangga, air yang didistribusikan melalui tangki air dan air yang digunakan untuk bahan makanan dan minuman yang disajikan kepada masyarakat, dimana harus memenuhi syarat kualitas air minum. ${ }^{2}$

Menurut Peraturan Menteri Kesehatan Republik Indonesia Nomor 492/MENKES/PER/IV/2010 tentang persyaratan air minum, pada pasal 3 ayat 1 dikatakan bahwa air minum harus memenuhi persyaratan fisika, mikrobiologis, kimiawi dan radioaktif. Persyaratan air minum secara Mikrobiologi dikatakan baik apabila air minum yang dipergunakan untuk keperluan rumah tangga memiliki kandungan bakteri coliform $0 / 100 \mathrm{ml}$ sampel air. ${ }^{3}$

Mikroba yang terdapat didalam air dapat merugikan terhadap kesehatan. Bakteri coliform merupakan bakteri pathogen yang terdapat pada usus manusia atau hewan berdarah panas. Bakteri coliform merupakan pencemaran oleh mikroorganisme yang berasal dari tinja manusia maupun kotoran hewan yang berdarah panas. Adapun dampak yang dapat ditimbulkan dari adanya bakteri coliform dalam air minum adalah dapat menyebabkan gangguan pencernaan seperti diare dan muntaber. Kehadiran bakteri coliform berpengaruh terhadap kesehatan manusia. ${ }^{4}$

Survei demografi dan kesehatan Indonesia (SDKI) tahun 2014, 15,5\% anak balita meninggal karena diare. Menurut World Health Organization (WHO), 94\% kasus diare yang diakibatkan oleh bakteri Escherichia Coli (E.Coli), dapat dicegah dengan meningkatkan akses air bersih, sanitasi, perilaku higienis, dan pengolahan air minum skala rumah tangga. ${ }^{2}$

Pemeriksaan sampel air minum secara bakteriologis dari depot air minum di Kabupaten Majalengka dilaksanakan setiap 3 (tiga) bulan sekali sesuai dengan Instruksi Bupati Majalengka nomor : 443.52/1630/Diskes tanggal 11 april 2003 tentang Pengawasan Kualitas Air Minum dimana jumlah target pemeriksaan sampel air minum dari depot air minum sebesar $100 \%$ (seluruh sampel air dari depot air minum diperiksa) dan jumlah target sampel yang memenuhi syarat kesehatan sebesar $100 \% .^{5}$

Sampel air minum dikatakan memenuhi syarat kesehatan secara mikrobiologi apabila jumlah bakteri e.coli dan Total Bakteri Coliform-nya 0 (nol) per jumlah $100 \mathrm{ml}$ sampel dengan kata lain tidak ditemukannya bakteri e.coli dalam sampel dengan kategori kelas A. ${ }^{3}$

Berdasarkan hasil pemeriksaan tahun 2013, ditemukan 162 depot dari 299 depot air minum di Kabupaten Majalengka tercemar oleh bakteri coliform dan 5,21\% tercemar oleh coli tinja. Hal ini disebabkan pencemaran air baku, lemahnya sistem filtrasi dan sistem transportasi untuk mengangkut air dari sumber menuju depot air minum, disisi lain akibat dari perilaku dan pengetahuan pedagang dalam mengemas air minum. ${ }^{6}$

Menurut penelitian tahun 2015, dari 5 depot air minum di Majalengka yang tercemar bakteri coli pada sampel air dari galon, ada indikasi bahwa ada perbedaan dalam karakteristik air baku, teknologi produksi atau proses operasi dan pemeliharaan yang diterapkan di depot air minum isi ulang. Keadaan higiene sanitasi tempat bangunan dan proses pengolahan kurang memenuhi syarat kesehatan dapat menjadi sumber keberadaan bakteriologis dan kontaminasi bahan kimia pada depot air minum isi ulang. Hasil pemeriksaan periode triwulan 
III dari 429 depot yang berada di Kabupaten Majalengka terdapat 103 depot air minum yang memenuhi syarat kesehatan. Ini menunjukan ada hubungan yang signifikan antara higiene sanitasi dan kualitas bakteriologis. ${ }^{7}$

Berdasarkan data-data tersebut di atas, keberadaan bakteri e.coli pada air minum isi ulang dan adanya kontaminasi bahan kimia pada depot air minum isi ulang diakibatkan karena pencemaran air baku, lemahnya sistem filtrasi dan sistem transportasi untuk mengangkut air dari sumber menuju depot air minum, disisi lain akibat dari perilaku dan pengetahuan pedagang dalam mengemas air minum serta keadaan higiene sanitasi tempat bangunan dan proses pengolahan kurang memenuhi syarat kesehatan. ${ }^{7}$

Tujuan penelitian ini adalah untuk mengetahui faktor-faktor yang berhubungan dengan kualitas air minum secara bakteriologis pada depot air minum di Kabupaten Majalengka tahun 2017.

\section{METODE PENELITIAN}

Rancangan penelitian yang digunakan adalah penelitian penjelasan (explanatory research), dengan pendekatan cross sectional. Variabel bebas dalam penelitian ini adalah lokasi kegiatan depot air minum, bangunan depot air minum, sumber air baku depot air minum dan alat produksi depot air minum. Variabel terikat dari penelitian ini adalah kualitas air secara bakteriologis pada depot air minum. Populasi pada penelitian ini adalah semua sampel air dari depot air minum di Kabupaten Majalengka pada pemeriksaan sampel periode triwulan IV tahun 2016 yaitu sebanyak 336 sampel air. Sampel dalam penelitian ini adalah sebanyak 60 sampel air, sampel dipilih dengan cara pengambilan sampel secara acak sederhana (simple random sampling). Instrumen penelitian atau perangkat yang digunakan untuk mengungkapkan data penelitian ini adalah checklist. Checklist yang digunakan dalam penelitian ini diambil dari checklist Pedoman Pengawasan Higiene Sanitasi Depot Air Minum yang diterbitkan oleh Seksi Penyehatan Lingkungan Tempat-Tempat Umum dan Industri (TTU \& I) Sub Dinas Penyehatan Lingkungan Dinas Kesehatan Propinsi Jawa Barat Tahun 2004 yang merupakan penjabaran dari Pedoman Pengawasan Higiene Sanitasi Depot Air Minum Direktorat Penyehatan Air dan Sanitasi kerjasama WHO dan Departemen Kesehatan Republik Indonesia Tahun 2003.

\section{HASIL PENELITIAN}

\section{Lokasi kegiatan depot air minum}

Tabel 1. Distribusi Depot Air Minum Berdasarkan Lokasi Kegiatan

\begin{tabular}{lcc}
\hline \multicolumn{1}{c}{ Lokasi kegiatan } & Frekuensi & $\%$ \\
\hline Tidak memenuhi syarat & 26 & 43,3 \\
Memenuhi syarat & 34 & 56,7 \\
\hline Jumlah Total & 60 & 100 \\
\hline
\end{tabular}

Dari tabel 1 terlihat bahwa lokasi kegiatan depot yang memenuhi syarat sebanyak 34 depot air minum $(56,7 \%)$.

\section{Keadaan bangunan depot air minum}

Tabel 2. Distribusi Depot Air Minum Berdasarkan Keadaan Bangunan

\begin{tabular}{lcc}
\hline \multicolumn{1}{c}{ Bangunan Depot } & Frekuensi & $\%$ \\
\hline Tidak memenuhi syarat & 6 & 10 \\
Memenuhi syarat & 54 & 90 \\
\hline Jumlah Total & 60 & 100 \\
\hline
\end{tabular}


Dari tabel 2 terlihat bahwa bangunan depot yang memenuhi syarat sebanyak 54 depot air minum $(90 \%)$.

\section{Sumber air baku depot air minum}

Tabel 3. Distribusi Depot Air Minum Berdasarkan Sumber Air Baku

\begin{tabular}{lcc}
\hline \multicolumn{1}{c}{ Sumber air baku } & Frekuensi & $\%$ \\
\hline Tidak memenuhi syarat & 9 & 15 \\
Memenuhi syarat & 51 & 85 \\
\hline Jumlah Total & 60 & 100 \\
\hline
\end{tabular}

Dari tabel 3. terlihat bahwa sumber air baku yang memenuhi syarat sebanyak 51 depot air minum $(85 \%)$.

\section{Alat produksi depot air minum}

Tabel 4. Distribusi Depot Air Minum Berdasarkan Alat Produksi

\begin{tabular}{lcc}
\hline \multicolumn{1}{c}{ Alat Produksi Depot } & Frekuensi & $\%$ \\
\hline Tidak memenuhi syarat & 27 & 45 \\
Memenuhi syarat & 33 & 55 \\
\hline Jumlah Total & 60 & 100 \\
\hline
\end{tabular}

Dari tabel 4. terlihat bahwa sumber air baku yang tidak memenuhi syarat sebanyak 33 depor air minum $(55 \%)$.

\section{Kualitas air secara bakteriologis}

Tabel 5. Distribusi Depot Air Minum Berdasarkan Kualitas Air Minum Secara Bakteriologis

\begin{tabular}{lcc}
\hline Kualitas air minum secara bakteriologis & Frekuensi & $\%$ \\
\hline Tidak memenuhi syarat & 15 & 25 \\
Memenuhi syarat & 45 & 75 \\
\hline Jumlah Total & 60 & 100 \\
\hline
\end{tabular}

Dari tabel 5. terlihat bahwa kualitas air minum yang memenuhi syarat sebanyak 45 depot air minum (75\%).

\section{Hubungan variabel independen dengan kualitas air minum secara bakteriologis pada depot air minum}

Berdasarkan tabel 6 hasil uji statistik menunjukkan bahwa terdapat 2 (dua) variabel independen yang mempunyai hubungan bermakna yang mempunyai nilai $p<0,05$ dengan variabel dependen, yang terdiri dari variabel lokasi kegiatan depot air minum dan alat produksi depot air minum. 
Tabel 6. Hubungan variabel independen dengan kualitas air minum secara bakteriologis pada depot air minum di Kabupaten Majalengka tahun 2017

\begin{tabular}{|c|c|c|c|c|}
\hline \multirow{2}{*}{ Variabel Independen } & \multicolumn{2}{|c|}{$\begin{array}{l}\text { Kualitas Air Minum Secara } \\
\text { Bakteriologis }\end{array}$} & \multirow{2}{*}{ Jumlah } & \multirow{2}{*}{$P$ value } \\
\hline & $\begin{array}{l}\text { Tidak memenuhi } \\
\text { syarat }\end{array}$ & $\begin{array}{l}\text { Memenuhi } \\
\text { syarat }\end{array}$ & & \\
\hline Lokasi kegiatan & & & & \\
\hline 1. Tidak memenuhi syarat & $19(73,1 \%)$ & $7(26,9 \%)$ & $26(100 \%)$ & \\
\hline $\begin{array}{l}\text { 2. Memenuhi syarat } \\
\text { Bangunan depot }\end{array}$ & $14(41,2 \%)$ & $20(58,8 \%)$ & $34(100 \%)$ & $\mathbf{0 , 0 0 2}$ \\
\hline 1. Tidak memenuhi syarat & $4(66,7 \%)$ & $2(33,3 \%)$ & $6(100 \%)$ & \\
\hline $\begin{array}{l}\text { 2. Memenuhi syarat } \\
\text { Sumber air baku }\end{array}$ & $29(53,7 \%)$ & $25(46,3 \%)$ & $54(100 \%)$ & 0,634 \\
\hline 1. Tidak memenuhi syarat & $5(55,6 \%)$ & $4(44,4 \%)$ & $9(100 \%)$ & \\
\hline $\begin{array}{l}\text { 2. Memenuhi syarat } \\
\text { Alat produksi }\end{array}$ & $28(54,9 \%)$ & $23(45,1 \%)$ & $51(100 \%)$ & 0,095 \\
\hline 1. Tidak memenuhi syarat & $24(89,9 \%)$ & $3(11,1 \%)$ & $27(100 \%)$ & \\
\hline 2. Memenuhi syarat & $9(27,3 \%)$ & $24(72,7 \%)$ & $33(100 \%)$ & $\mathbf{0 , 0 0 0}$ \\
\hline
\end{tabular}

\section{PEMBAHASAN}

Menurut Peraturan Menteri Kesehatan Republik Indonesia Nomor 492/MENKES/PER/IV/2010 tentang persyaratan air minum, pada pasal 3 ayat 1 dikatakan bahwa air minum harus memenuhi persyaratan fisika, mikrobiologis, kimiawi dan radioaktif. Persyaratan air minum secara Bakteriologi dikatakan baik apabila air minum yang dipergunakan untuk keperluan rumah tangga memiliki kandungan bakteri coliform 0/100 ml sampel air. ${ }^{3}$

Dengan kemajuan teknologi, maka masyarakat dalam memenuhi kebutuhan air minum dalam bentuk kemasan karena selain praktis air minum ini dianggap lebih higienis. Produksi air minum dalam kemasan biasanya dilakukan industri besar dengan melalui proses secara otomatis dan disertai dengan pengujian kualitas mikrobiologi yang telah memenuhi syarat, akan tetapi lama kelamaan masyarakat merasakan air minum dalam kemasan semakin mahal. Saat ini masyarakat mulai beralih pada air minum yang berasal dari depot isi ulang, dikarenakan air minum isi ulang harganya lebih murah dibanding air minum kemasan. Dalam mengisi air minum isi ulang masyarakat mengisi galon yang dibawanya ke depot air minum, akan tetapi banyak masyarakat yang masih meragukan kualitas air minum isi ulang tersebut karena belum ada informasi yang lebih jelas baik dari segi proses pengolahan depot air minum, perizinan maupun peraturan kelaikan air minum isi ulang dan pengawasan terhadap depot tersebut. ${ }^{8}$

Pengolahan air minum dilakukan tergantung dari kualitas air baku yang digunakan baik pengolahan sederhana sampai dengan pengolahan yang kompleks. Pengolahan air baku ini dimaksudkan untuk memperbaiki kualitas air sehingga aman dan tidak membahayakan bagi kesehatan masyarakat yang menggunakannya. ${ }^{2}$

Menurut Pedoman dan Pengawasan Higiene Sanitasi Depot Air Minum kerjasama antara WHO dan Departemen Kesehatan RI tahun 2003, bahwa faktor-faktor yang berhubungan dengan kualitas air minum secara bakteriologis itu terdiri dari lokasi kegiatan, bangunan, sumber air baku, tandon air baku, alat produksi, proses pengemasan, sarana pelengkap, managemen mutu, pengendalian mutu, pengawasan kebersihan dan PHBS karyawan. ${ }^{3}$ 


\section{Hubungan antara lokasi kegiatan dengan kualitas air minum secara bakteriologis}

Hasil dari penelitian ini menunjukkan bahwa persentase lokasi kegiatan depot yang MS lebih banyak dibandingkan dengan yang TMS dengan hasil uji chi square nilai $p=0,002$ $(p<0,05)$. Secara statistik menunjukkan ada hubungan antara lokasi kegiatan dengan kualitas air minum secara bakteriologis.

Hal ini sesuai dengan penelitian Paulina Aziz di Kota Pekanbaru tahun 2008, bahwa lokasi depot air minum harus terbebas dari pencemaran yang berasal dari debu sekitar depot, daerah tempat pembuangan sampah, tempat penumpukan sampah, tempat penumpukan barang bekas, tempat bersembunyi/berkembangbiak serangga, binatang kecil, pengerat serta tempat yang kurang baik system pembuangan air. ${ }^{9}$

Menurut Pedoman Pengawasan Higiene Sanitasi Depot Air Minum persyaratan lokasi kegiatan depot itu harus jauh dari daerah tergenang air dan rawa, tempat pembuangan kotoran dan sampah, penumpukan barang-barang bekas atau bahan berbahaya dan beracun dan daerah lain yang diduga dapat menimbulkan pencemaran terhadap air minum, perusahaanaanlain yang menimbulkan pencemaran, seperti bengkel cat las, kapur, asbes dan sejenisnya serta harus jauh dari tempat pembuangan kotoran (tinja) umum, terminal bus, atau daerah padat pencemaran lainnya. Harus ada pekarangan cukup luas untuk parkir kendaraan, permukaan rapat air dan cukup miring dan kebersihan terjaga bebas dari kegiatan lain. ${ }^{6}$

Berdasarkan penelitian lokasi kegiatan depot sebagian besar berada dekat dengan sumber pencemar antara lain bengkel, pasar, selokan yang dapat mempengaruhi kualitas air minum secara bakteriologis. Karena itu maka penulis berasumsi bahwa lokasi kegiatan depot dapat berpengaruh terhadap kualitas air minum secara bakteriologis.

\section{Hubungan antara bangunan dengan kualitas air minum secara bakteriologis}

Dari hasil uji beda proporsi dengan chi square (nilai $\mathrm{p}=0,634$ ) ternyata tidak ada hubungan antara bangunan depot dengan kualitas air minum secara bakteriologis. Dengan demikian hipotesis yang menyatakan ada hubungan antara bangunan dan kualitas air minum secara bakteriologis tidak didukung dengan data. Hal ini sesuai dengan penelitian yang dilakukan oleh Galih Wahyu di Kabupaten Jember tahun 2007 bahwa variabel bangunan depot memenuhi syarat sebesar $81,70 \%$ dengan menggunakan uji chi square diketahui tidak ada hubungan yang signifikan antara sanitasi bangunan dengan kualitas bakteriologi (mikrobiologi). ${ }^{10}$

Hasil ini berbeda dengan penelitian Sri Malem di Kota Medan tahun 2009 yang menyatakan bahwa keadaan higiene sanitasi tempat bangunan yang kurang memenuhi syarat kesehatan dapat menjadi sumber keberadaan bakteriologi (mikrobiologi) dan kontaminasi bahan kimia pada depot air minum. ${ }^{7}$

Sebagian besar bangunan depot air minum sudah memenuhi persyaratan sesuai dengan persyaratan depot air minum, hal ini tidak tidak terlepas dari peran serta petugas sanitarian puskesmas yang sentiasa memberikan penyuluhan dan tindakan yang tegas sesuai peraturan pada saat pengambilan dan pengiriman sampel juga peranan pengurus ASPADA di Kabupaten Majalengka yang selalu rutin mengadakan pertemuan untuk peningkatan pengetahuan para pemilik atau pengelola depot air minum.

\section{Hubungan antara sumber air baku dengan kualitas air minum secara bakteriologis}

Dari hasil penelitian didapat nilai $p=0,095(p>0,05)$ artinya tidak ada hubungan antara sumber air baku dengan kualitas air minum secara bakteriologis. Dengan demikian tidak terbukti hipotesis yang menyatakan ada hubungan antara sumber air baku dengan kualitas air minum secara bakteriologis.

Hasil penelitian ini berbeda dengan penelitian Pitoyo tahun 2007 yang mengatakan bahwa ada beberapa penyebab air minum terkontaminasi diantaranya bersumber dari air 
baku, wadah tempat distribusi tidak memenuhi standar higiene dan sanitasi depot air minum. ${ }^{11}$ Sedangkan menurut Sri Malem dalam penelitiannya melaporkan bahwa berdasarkan uji statistik tidak ada perbedaan yang bermakna antara parameter kualitas air pada sampel air dari mobil tanki, air baku dan air galon dari semua parameter kualitas air. ${ }^{7}$

Dari hasil penelitian di atas dapat diasumsikan bahwa sumber air baku yang banyak digunakan responden adalah PDAM yang sudah mendapat rekomendasi dari dinas kesehatan atau instansi yang berwenang sesuai dengan standar persyaratan yang telah ditentukan. ${ }^{12}$ Masih ada depot air minum yang masih menggunakan sumber air baku berasal dari sumur pompa atau sumur gali, karena pengolahannya sesuai prosedur maka hasil pemeriksaan terhadap sampel air minum memenuhi syarat.

\section{Hubungan antara alat produksi dengan kualitas air minum secara bakteriologis}

Analisis hubungan antara alat produksi dengan kualitas air minum secara bakteriologis, mengungkapkan hasil bahwa depot air minum yang mempunyai alat produksi yang memenuhi syarat lebih banyak dibanding dengan yang tidak memenuhi syarat.

Hasil uji statistik menunjukan nilai $p=0,000(p<0,05)$, hal ini menunjukkan bahwa ada hubungan yang bermakna antara alat produksi dengan kualitas air minum secara bakteriologis, dengan demikian hipotesis menyatakan ada hubungan antara alat produksi dengan kualitas air minum secara bakteriologis didukung oleh data. Hal ini sesuai dengan penelitian Pitoyo tahun 2007 yang menyatakan bahwa penyebab air minum terkontaminasi diantaranya karena proses filtrasi dan desinfeksi dengan teknologi yang rendah. ${ }^{11}$ Menurut survey yang dilakukan Suklan tahun 2010 ditemukan bahwa 96 depot dari 1200 depot tersemar oleh bakteri coliform hal ini disebabkan oleh lemahnya sistem filtrasi dan sistem transportasi untuk mengangkut air dari sumber menuju depot air minum. ${ }^{13}$

Alat produksi yang digunakan harus memiliki sertifikat SNI atau ISO. Dengan persyaratan filter antara lain terbuat dari bahan yang mudah pemeliharaannya, wadah tabung filter harus dari bahan food grade. Tandon air hasil filtrasi harus terlindung dari jamahan serangga dan tikus serta tidak menjadi tempat perindukan nyamuk (jentik) dan terbuat dari bahan yang tidak dapat melepaskan zat-zat beracun ke dalam air seperti food grade stainless steel dan wadah berlapis polycarbonate atau poly-vinyl-carbonate. ${ }^{14}$

Mikro filter untuk penyaringan air bersih yang kedua agar bakteri, virus dan partikel halus lainnya dapat tersaring dengan baik dan memiliki indikator untuk kepentingan pemantauan dan perbaikan. Desinfeksi tidak menimbulkan dampak radioaktif yang membahayakan bagi kesehatan masyarakat serta harus mampu membunuh kuman pathogen dalam air minum, tetapi tidak menimbulkan perubahan struktur pada air minum. Pompa dan pipa penyalurterbuat dari bahan yang tidak dapat melepaskan zat-zat beracun ke dalam air seperti food grade stainless steel dan wadah berlapis polycarbonate atau poly-vinyl-carbonate dan dianjurkan untuk menggunakan peralatan yang tembus pandang sehingga mudah dilakukan pemantauan. ${ }^{14}$

Dari hasil penelitian diketahui bahwa sebagian besar depot menggunakan filter yang tidak berlisensi (ISO atau SNI) serta bahan wadah tabung filter tidak terbuat dari food grade stainless steel, sedangkan desinfeksi (Ultra violet atau Ozon) sebagian besar tidak selalu menyala (standby) hanya pada saat beroperasi saja seharusnya desinfeksi standby dengan lampu indikator yang selalu menyala. Dengan asumsi ini dapat disimpulkan bahwa alat produksi yang memenuhi syaratakan menpengaruhi kualitas secara bakteriologis yang memenuhi syarat pula.

\section{KESIMPULAN}

1. Lokasi kegiatan depot air minum yang memenuhi syarat adalah sebanyak $56,7 \%$.

2. Bangunan depot air minum yang memenuhi syarat adalah sebanyak $90 \%$. 
3. Sumber air baku depot air minum yang memenuhi syarat adalah sebanyak $85 \%$.

4. Alat produksi depot air minum yang memenuhi syarat adalah sebanyak $55 \%$.

5. Kualitas air minum secara bakteriologis pada depot air minum di Kabupaten Majalengka tahun 2017 yang memenuhi syarat sebanyak 45 depot air minum (75\%) dan tidak memenuhi syarat 15 depot air minum $(25 \%)$.

6. Ada hubungan antara lokasi kegiatan dengan kualitas air minum secara bakteriologis pada depot air minum di Kabupaten Majalengka tahun 2017, berdasarkan uji statistik chi square dengan nilai $p=0,002$ ( $p$ value $<0,05)$.

7. Tidak ada hubungan antara bangunan depot dengan kualitas air minum secara bakteriologis pada depot air minum di Kabupaten Majalengka tahun 2017, berdasarkan uji statistik chi square didapat nilai $p=0,634$ ( $p$ value $>0,05)$.

8. Tidak ada hubungan antara sumber air baku depot dengan kualitas air minum secara bakteriologis pada depot air minum di Kabupaten Majalengka tahun 2017, berdasarkan uji statistik chi square didapat nilai $p=0,095$ ( $p$ value $>0,05)$.

9. Ada hubungan antara alat produksi depot dengan kualitas air minum secara bakteriologis pada depot air minum di Kabupaten Majalengka tahun 2017, berdasarkan uji statistik chi square dengan nilai $p=0,000$ ( $p$ value $<0,05)$.

\section{SARAN}

\section{Akademik}

1. Bagi ilmu pengetahuan, dapat dijadikan sebagai pembendaharaan ilmu pengetahuan dan kepustakaan di bidang penyediaan air minum.

2. Menambah pengetahuan penulis dalam melaksanakan penelitian khususnya tentang hubungan antara lokasi kegiatan depot, bangunan depot, air baku dan alat produksi depot dengan kualitas air minum secara bakteriologis pada depot air minum di Kabupaten Majalengka Tahun 2017.

\section{Praktis}

1. Bagi Dinas Kesehatan Kabupaten Majalengka

Pengawasan dan pembinaan yang terus menerus dari Dinas kesehatan maupun puskesmas setempat kepada pengelola depot terutama untuk persyaratan teknis depot air minum.

2. Bagi pemilik atau pengelola depot air minum

Disarankan agar mengadakan pengawasan implementasi sertifikasi laik higiene sanitasi dengan memodifikasi lingkungan sesuai persyaratan, dan tindakan penegakan peratuan, dengan maksud :

(1) Menjaga kualitas air minum secara teratur menjamin kemanan produk bagi konsumen;

(2) Menjaga kualitas sarana bangunan, produksi dan kualitas sumber air baku serta kualitas alat pengangkutan air baku dengan cara melakukan pemeliharaan dan penggantian sarana secara rutin.

3. Perlu dilakukan penelitian lanjutan dengan memakai desain kasus kontrol, kohort atau studi eksperimental dengan mencoba variabel bebas yang lain.

\section{DAFTAR PUSTAKA}

1. C Totok Sutrisno, dkk. Teknologi Penyediaan Air Bersih. Edisi Baru, cetakan ke 6. Jakarta; Rineka Cipta; 2006.

2. Yance Warman, S.Ked. Pengawasan Kualitas Air Minum Isi Ulang oleh Dinas Kesehatan Kota Pekanbaru Tahun 2008. Fakultas Kedokteran Universitas Riau. 5 September 2008. [Diakses tanggal 22 Desember 2016]. Tersedia dari Posted on September 5, 2008 
3. Departemen Kesehatan Republik Indonesia, Peraturan Menteri Kesehatan Republik Indonesia Nomor 492/ MENKES/ PER/ IV/ 2010 tentang Persyaratan Kualitas Air Minum, Jakarta; 2010

4. Edi Suriaman dan Juwita, Uji Kualitas Air. Universitas Islam Negeri Malang. 2008. [Diakses tanggal 22 Desember 2016]. Tersedia dari www.scribd.com

5. Dinas Kesehatan Kabupaten Majalengka, Surat Edaran Bupati Majalengka nomor 443.52/ 1630/ Diakses tertanggal 11 April 2003 tentang Pengawasan Kualitas Air Minum. Majalengka; 2003

6. Bambang Suprihatin, Hubungan Higiene Sanitasi Depot terhadap kualitas bakteriologis air minum isi ulang. Skripsi. Surabaya: Fakultas Kesehatan Masyarakat Universitas Airlangga; 2007

7. Sri Malem Indirawati, Analisis Higiene Sanitasi dan Kualitas Air Minum Isi Ulang (AMIU) berdasarkan Sumber Air Baku pada Depot Air Minum di Kota Medan.Tesis. Medan. Sekolah Pasca Sarjana Universitas Sumatera Utara; 2009

8. Shofyan Zuhri, Pemeriksaan Mikrobiologis Air Minum Isi Ulang Di Kecamatan Jebres Kota Surakarta Tahun 2009. Skripsi. Surakarta: Fakultas Farmasi Universitas Muhammadiyah; 2009

9. Paulina Aziz, Kajian Kualitas Air Minum Isi Ulang di Kota Pekanbaru. Jurnal penelitian Teroka Riau. 2008; vol.VIII no. 4 September, 46-59

10. Wahyu Galih, Analisis Higiene Kualitas Air Minum Berdasarkan Bangunan di Kabupaten Jember; 2007

11. Pitoyo, Kualitas Air Minum Secara Bakteriologis; 2007

12. Dinas Kesehatan Kabupaten Majalengka, Evaluasi Penyehatan Lingkungan Tahun 2015. Majalengka; 2015. 11-17

13. Suklan, Hasil Survey Terhadap Depot Air Minum. Jakarta; 2011

14. Departemen Kesehatan Propinsi Jawa Barat, Pedoman Pengawasan Hygiene Sanitasi Depot Air Minum, Seksi Penyehatan Lingkungan TTU \& I Dirjen P2PL Kementerian Kesehatan, Bandung; 2010 